\title{
Ionic Liquid Composite Polymer Electrolyte Membranes for the Unhumidified Intermediate Temperature Fuel Cell
}

\section{$\operatorname{AUTHOR(S):~}$}

Lee, J. S.; Nohira, T.; Hagiwara, R.

\section{CITATION:}

Lee, J. S....[et al]. Ionic Liquid Composite Polymer Electrolyte Membranes for the

Unhumidified Intermediate Temperature Fuel Cell. ECS Transactions 2006, 3(1): 55-62

\section{ISSUE DATE:}

2006

URL:

http://hdl.handle.net/2433/260597

\section{RIGHT:}

This is the Accepted Manuscript version of an article accepted for publication in ECS Transactions. The Electrochemical Society and IOP Publishing Ltd are not responsible for any errors or omissions in this version of the manuscript or any version derived from it. The Version of Record is available online at https://doi.org/10.1149/1.2356123.; This is not the published version. Please cite only the published version.; この論文は出版社版でありません。引用の際には出版社版

をご確認ご利用ください。 


\title{
Ionic Liquid Composite Polymer Electrolyte Membranes for the Unhumidified Intermediate Temperature Fuel Cell
}

\author{
J. S. Lee, T. Nohira, and R. Hagiwara \\ Department of Fundamental Energy Science, Graduate School of Energy Science, \\ Kyoto University, Sakyo-ku, Kyoto 606-8501, Japan
}

\begin{abstract}
We synthesized novel composite polymer electrolyte membranes of $[\mathrm{EMIm}](\mathrm{FH})_{n} \mathrm{~F}(n=1.3$ and 2.3) ionic liquids and measured their physical and electrochemical properties. The ionic conductivities of composite membrane (P(VdF-co-HFP):s-DFBPHFDP:[EMIm] $(\mathrm{FH})_{2.3} \mathrm{~F}=1: 0.3: 1.75$ in weight ratio) were up to 11.3 and $34.7 \mathrm{mS} \mathrm{cm}^{-1}$ at 25 and $130{ }^{\circ} \mathrm{C}$, respectively. We also studied the fuel cell performance using these composite membranes at intermediate temperature without humidification. The OCV observed for the cell using [EMIm] $(\mathrm{FH})_{2.3} \mathrm{~F}$ composite electrolyte was $\sim 1.0 \mathrm{~V}$ at $130{ }^{\circ} \mathrm{C}$ and stable during the measurement conducted for over $5 \mathrm{~h}$. The maximum power density of $14.8 \mathrm{~mW} \mathrm{~cm}^{-2}$ was observed at $37.2 \mathrm{~mA} \mathrm{~cm}^{-2}$ at $120{ }^{\circ} \mathrm{C}$. From the high thermal stability and high ionic conductivity, the fluorohydrogenate ionic liquid composite membranes seem to be promising candidate electrolytes for unhumidified PEMFCs at intermediate temperature.
\end{abstract}

\section{Introduction}

The object of this work is to develop the novel polymer electrolyte membranes for unhumidified fuel cells by using ionic liquids. The polymer electrolyte membrane fuel cells (PEMFCs) are the most promising candidates for large-scale commercialization of fuel cells and are being extensively studied (1). Nafion ionomer membrane is most widely studied and used in PEMFCs because of its excellent chemical, physical, and electrical properties $(2,3)$. The major drawback of the Nafion membrane, however, is that the conductivity drops at temperatures higher than $100{ }^{\circ} \mathrm{C}$ due to the evaporation of water. High cost, complex synthetic process, using expensive catalysts, and the low thermal stability at high temperature are also disadvantages of Nafion for PEMFC applications.

Operation at higher temperature than $100{ }^{\circ} \mathrm{C}$ without humidification is required by several reasons (1,4-7): (i) the carbon monoxide is absorbed on the $\mathrm{Pt}$ anode electrocatalyst, competitive of $\mathrm{H}_{2}$. The absolute free energy of adsorption of $\mathrm{CO}$ on $\mathrm{Pt}$ has larger positive temperature dependence than that of $\mathrm{H}_{2}$. The $\mathrm{CO}$ poisoning effect, therefore, can be prevented at elevated temperatures over $100{ }^{\circ} \mathrm{C}$; (ii) higher temperature operation can improve thermal management. A smaller cooling system is desirable and the generated heat can be used effectively. Also, it can increase reaction rates at both electrodes, activate catalyst layer, and improve the power generation efficiency; (iii) the problem of water management can also be solved very easily. The unhumidified PEMFCs do not use water, therefore, it can be operated at over $100{ }^{\circ} \mathrm{C}$ without the deterioration of cell performance and the water management is not needed. 
Recently, several proton conducting membranes were developed for high temperature operation, including modified perfluorosulfonic acid (PFSA) polymer membranes, alternative sulfonated polymers and their inorganic composite membranes, acid-base complex membranes, and ionic liquid-based gel-type proton conducting membranes $(1,8,9)$

A fuel cell operating without humidification and driven by hydrogen transfer via fluorohydrogenate anions, $(\mathrm{FH})_{n} \mathrm{~F}^{-}$, has been constructed using a room temperature ionic liquid, 1-ethyl-3-methylimidazolium fluorohydrogenates, [EMIm] $(\mathrm{FH})_{n} \mathrm{~F}(n=1.3$ and 2.3) (10). In the present work, we synthesized novel composite polymer electrolyte membranes of $[\mathrm{EMIm}](\mathrm{FH})_{n} \mathrm{~F}$ and measured their physical and electrochemical properties. We also studied the fuel cell performance using these composite membranes at temperatures over $100{ }^{\circ} \mathrm{C}$ without humidification.

\section{Experiments}

\section{Syntheses of Composite Membranes}

$[\mathrm{EMIm}](\mathrm{FH})_{n} \mathrm{~F}$ ( $n=1.3$ and 2.3) were prepared according to the previous report (11). Poly(vinylidene-fluoride-co-hexafluoropropylene) (P(VdF-co-HFP), Aldrich) and other reagents were used as received. The sulfonated-fluorinated poly(arylene ether) was prepared from decafluorobiphenyl (DFBP, Wako) and 4,4'-(hexafluoropropylidene) diphenol (HFDP, Aldrich) by the modified synthetic methods reported previously (12).

The preparation of the poly(decaflouorobiphenyl-(hexafluoropropylidene)diphenol (DFBP-HFDP). A mixture of $3.40 \mathrm{~g}(0.01 \mathrm{~mol})$ of decafluorobiphenyl, $3.43 \mathrm{~g}(0.01 \mathrm{~mol})$ of 4,4'-(hexafluoropropylidene)diphenol, and $70 \mathrm{~mL}$ of $N, N$-dimethylacetamide were put in a $250 \mathrm{~mL}$ round bottomed flask equipped with a condenser and stirred until the mixture was completely dissolved. Potassium carbonate (Wako, $4.14 \mathrm{~g}, 0.03 \mathrm{~mol}$ ) was added to the mixture above and heated up to $160{ }^{\circ} \mathrm{C}$. After $2 \mathrm{~h}$ of heating and stirring, the reaction mixture was poured into rapidly stirred distilled water containing $1 \mathrm{wt} \%$ of acetic acid to precipitate the polymer. The precipitates were filtered and washed with distilled water until the $\mathrm{pH}$ reached neutral to remove the excess potassium carbonate and acetic acid. A white powdery DFBP-HFDP was obtained after drying.

Sulfonation and casting. DFBP-HFDP (2 g) was dissolved with $100 \mathrm{~mL}$ of chloroform in a flask equipped with a condenser. Then, fuming sulfuric acid $\left(30 \% \mathrm{SO}_{3}\right)$ was added into the flask dropwise and the mixture was vigorously stirred for $4 \mathrm{~h}$. The sulfonated DFBP-HFDP (s-DFBP-HFDP) was precipitated in distilled water and then filtered. To remove unreacted sulfuric acid, the s-DFBP-HFDP was washed with distilled water until the $\mathrm{pH}$ of the washed water reached neutral. A pale brown powdery s-DFBPHFDP was obtained after drying. Composite membranes were prepared by casting method by pouring the solution mixture of polymers and ionic liquids in a Teflon dish to evaporate solvent. The thickness and size of the membranes were varied by controlling the volume of the solution and the diameter of the plates.

\section{Characterizations}

A differential scanning calorimeter (Shimadzu DSC-60) was employed to study the thermal transition behavior of s-DFBP-HFDP and its composite membranes. The sample was heated under nitrogen from room temperature to $250{ }^{\circ} \mathrm{C}$ at $10{ }^{\circ} \mathrm{C} \mathrm{min}{ }^{-1}$. The thermal 
stability of composite membranes was investigated by means of a thermogravimetric analyzer (Shimadzu DTG-60) from 50 to $600{ }^{\circ} \mathrm{C}$ at a heating rate of $10{ }^{\circ} \mathrm{C} \mathrm{min}{ }^{-1}$ under a nitrogen atmosphere. The ionic conductivities were measured by a PARSTAT 2273 frequency response analyzer (FRA) in the frequency range of $1 \mathrm{kHz}$ to $500 \mathrm{kHz}$. A conductivity cell containing two stainless steel blocking electrodes was used.

\section{Preparation of MEA and Single Cell Test}

The PEMFC single cell test was carried out with gas diffusion electrode with $\mathrm{Pt} / \mathrm{C}$ catalyst (E-TEK, Pt loading of $0.5 \mathrm{mg} \mathrm{cm}^{-2}$ ), ionic liquid was impregnated by brushing to improve the electrochemical contact between the electrodes and the membrane. The membrane electrode assembly (MEA) was prepared by pressing the electrode/ membrane/electrode sandwich (the geometric electrode area was $5 \mathrm{~cm}^{2}$ ) at a pressure of $0.3 \mathrm{MPa}$ at $100{ }^{\circ} \mathrm{C}$ for $5 \mathrm{~min}$. Dry oxygen and hydrogen, used as reactants, were flowed by the rate of $30 \mathrm{~mL} \mathrm{~min}{ }^{-1}$. Dry hydrogen and oxygen gases were obtained from Japan Air Gas Co. (Purity 99.999\%). Single cell tests were performed with the aid of a Hokuto Denko HZ-3000 electrochemical measurement system.

\section{Results and Discussion}

\section{Thermal Properties}

Thermal stability of fluorohydrogenate ionic liquid (FHIL) composite membranes was investigated from 50 to $600{ }^{\circ} \mathrm{C}$ at a heating rate of $10{ }^{\circ} \mathrm{C} \mathrm{min}{ }^{-1}$ under a nitrogen atmosphere. A weight loss for $\mathrm{P}\left(\mathrm{VdF}-\mathrm{co}\right.$-HFP) was observed at $310{ }^{\circ} \mathrm{C}$ and weight losses for s-DFBP-HFDP were observed at 275 and $530{ }^{\circ} \mathrm{C}$. These values were similar to the previous report and the former weight loss of s-DFBP-HFDP at $275{ }^{\circ} \mathrm{C}$ was attributed to the elimination of sulfonic acid groups (12). FHIL composite membranes did not show any significant difference by the kind and amount of FHIL in each composite membrane. Decomposition temperatures $\left(T_{\mathrm{d}}\right)$ of FHIL composite membranes were observed at 190$210{ }^{\circ} \mathrm{C}$ where the first irreversible weight losses occur; the second weight losses were observed at $270-310{ }^{\circ} \mathrm{C}$ (Figure 1). The first irreversible weight loss is identified as the decomposition of FHIL, the second one is originated from the elimination of sulfonic acid group of s-DFBP-HFDP and the degradation of $\mathrm{P}(\mathrm{VdF}-\mathrm{co}-\mathrm{HFP})$ backbone. It should be noted that neat $[\mathrm{EMIm}](\mathrm{FH})_{2.3} \mathrm{~F}$ is thermally less stable than $[\mathrm{EMIm}](\mathrm{FH})_{1.3} \mathrm{~F}$, releasing $\mathrm{HF}$ to become $[\mathrm{EMIm}](\mathrm{FH})_{1.3} \mathrm{~F}$ at $130{ }^{\circ} \mathrm{C}$. However, there is no apparent weight decrease observed in this temperature range suggesting the salt is stabilized by the interaction with the polymer.

The DSC curves of fluorohydrogenate ionic liquid (FHIL) composite membranes showed two endothermic signals at 135 and $205{ }^{\circ} \mathrm{C}$ corresponding to melting point $\left(T_{\mathrm{m}}\right)$ for $\mathrm{P}\left(\mathrm{VdF}-\mathrm{co}\right.$-HFP) and glass transition temperature $\left(T_{\mathrm{g}}\right)$ for s-DFBP-HFDP, respectively. These values did not show any significant difference by the kind of FHIL. However, $T_{\mathrm{m}}$ values of $\mathrm{P}(\mathrm{VdF}-\mathrm{co}$-HFP) were slightly decreased with increasing the amount of FHIL. This might be originated from the solubility of $\mathrm{P}(\mathrm{VdF}-$-co-HFP $)$ to the FHILs at temperatures over $100{ }^{\circ} \mathrm{C}$. However, these values are high enough to endure a high temperature operation over $100{ }^{\circ} \mathrm{C}$. 


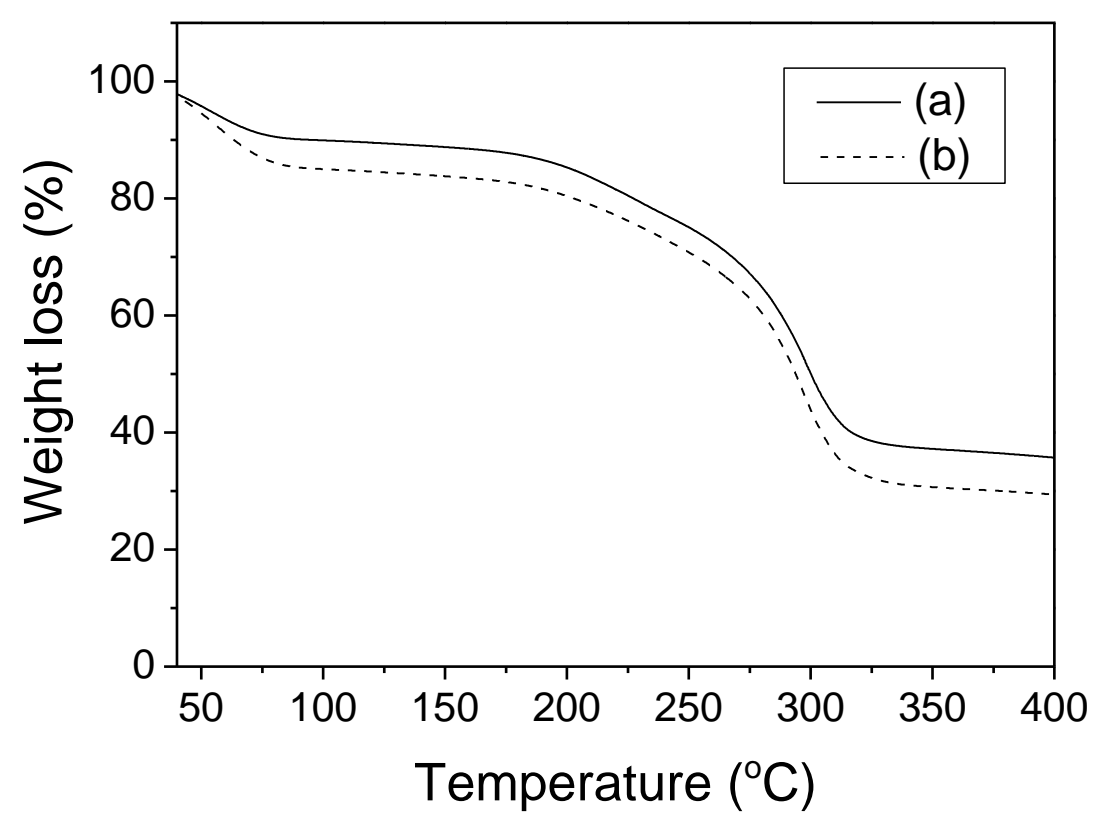

Figure 1. TGA curves for (a) P(VdF-co-HFP):s-DFBP-HFDP:[EMIm](FH) $)_{2.3} \mathrm{~F}=$ 1:0.3:1.25, (b) P(VdF-co-HFP):s-DFBP-HFDP:[EMIm] $(\mathrm{FH})_{2.3} \mathrm{~F}=1: 0.3: 1.75$.

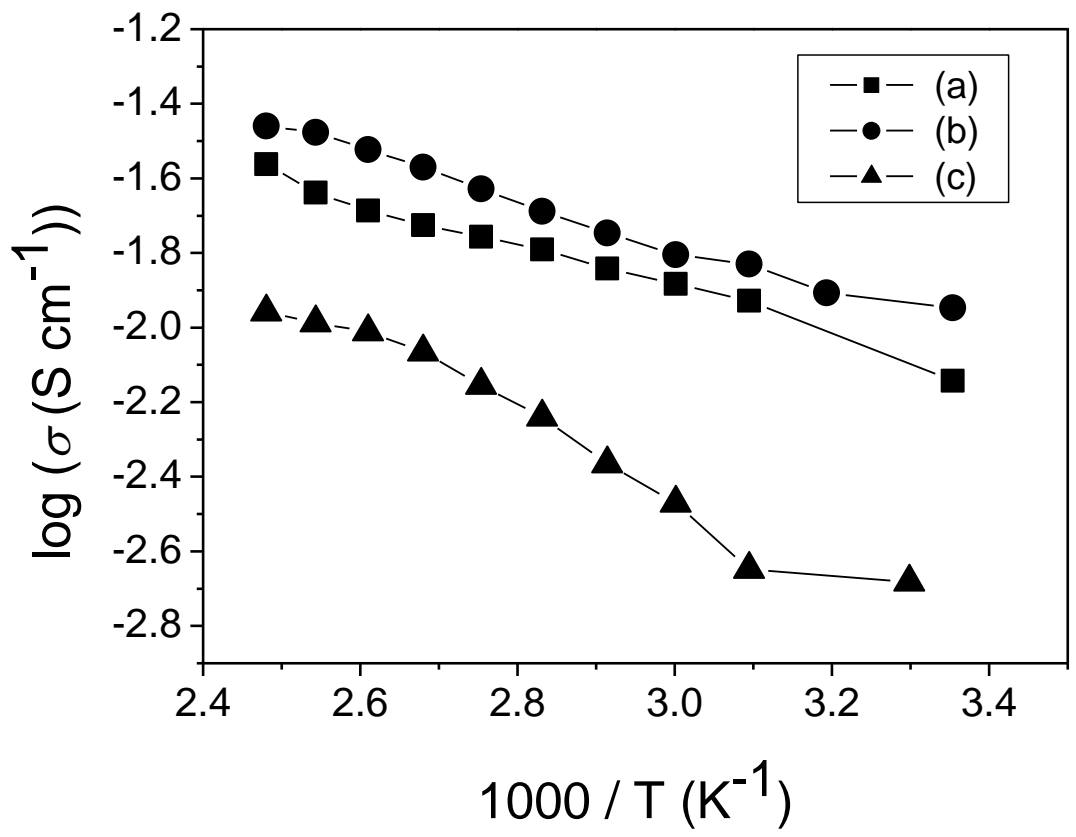

Figure 2. Ionic conductivities of FHIL composite membranes as a function of temperature. (a) P(VdF-co-HFP):s-DFBP-HFDP:[EMIm] $(\mathrm{FH})_{2.3} \mathrm{~F}=1: 0.3: 1.25$, (b) $\mathrm{P}(\mathrm{VdF}-c o-H F P): s-D F B P-H F D P:[E M I m](\mathrm{FH})_{2.3} \mathrm{~F}=1: 0.3: 1.75, \quad$ (c) $\mathrm{P}(\mathrm{VdF}-c o-H F P): \mathrm{s}-$ DFBP-HFDP:[EMIm] $(\mathrm{FH})_{1.3} \mathrm{~F}=1: 0.3: 0.75$. 


\section{$\underline{\text { Ionic Conductivities }}$}

The ionic conductivities of composite membranes were measured by two-probe AC impedance with a conductivity cell containing two stainless steel blocking electrodes. The weight ratio of $\mathrm{P}(\mathrm{VdF}-\mathrm{co}-\mathrm{HFP})$ and s-DFBP-HFDP was fixed to 1:0.3 and various amounts of $[\mathrm{EMIm}](\mathrm{FH})_{n} \mathrm{~F}(n=1.3$ and 2.3$)$ were added to make composite membranes.

In general, the ionic conductivity is proportional to the charge carrier density and its mobility. Therefore, the ionic conductivity increased with increasing FHIL and temperature (Figure 2): in the case of the ratio of $\mathrm{P}(\mathrm{VdF}-\mathrm{co}-\mathrm{HFP})$ :s-DFBPHFDP:[EMIm] $(\mathrm{FH})_{2.3} \mathrm{~F}$ was 1:0.3:1.25, the composite membrane showed ionic conductivities up to 7.2 and $27.4 \mathrm{mS} \mathrm{cm}^{-1}$ at 25 and $130{ }^{\circ} \mathrm{C}$, respectively. In the case of 1:0.3:1.75, it exhibited 11.3 and $34.7 \mathrm{mS} \mathrm{cm}^{-1}$ at 25 and $130{ }^{\circ} \mathrm{C}$, respectively. These relatively high ionic conductivities of FHIL composite membranes are due to the intrinsic high ionic conductivity of neat $[\mathrm{EMIm}](\mathrm{FH})_{2.3} \mathrm{~F}$. However, the FHIL composite membranes containing over 2 times ionic liquids to polymers could not be obtained. When the weight ratio was $\mathrm{P}\left(\mathrm{VdF}-\mathrm{co}\right.$-HFP):s-DFBP-HFDP:[EMIm] $(\mathrm{FH})_{1.3} \mathrm{~F}=1: 0.3: 0.75$, the lower ionic conductivity was observed at the values of 2.1 and $11.0 \mathrm{mS} \mathrm{cm}^{-1}$ at 30 and $130{ }^{\circ} \mathrm{C}$, respectively. This result is due to not only the small amount of FHIL but also lower intrinsic ionic conductivity of $[\mathrm{EMIm}](\mathrm{FH})_{1.3} \mathrm{~F}$ than $[\mathrm{EMIm}](\mathrm{FH})_{2.3} \mathrm{~F}$. The FHIL composite membranes containing $[\mathrm{EMIm}](\mathrm{FH})_{2.3} \mathrm{~F}$ are good candidates for PEMFC due to their high ionic conductivity.

\section{$\underline{\text { Single Cell Tests of Composite Membranes }}$}

The principle of the FHIL-PEMFC is shown below. The cathode, anode, and total reactions for the $[\mathrm{EMIm}](\mathrm{FH})_{2.3} \mathrm{~F}$ fuel cell are

$$
\begin{array}{ll}
\text { Cathode } & 1 / 2 \mathrm{O}_{2}+6(\mathrm{FH})_{3} \mathrm{~F}^{-}+2 \mathrm{e}^{-} \rightarrow \mathrm{H}_{2} \mathrm{O}+8(\mathrm{FH})_{2} \mathrm{~F}^{-} \\
\text {Anode } & \mathrm{H}_{2}+8(\mathrm{FH})_{2} \mathrm{~F}^{-} \rightarrow 6(\mathrm{FH})_{3} \mathrm{~F}^{-}+2 \mathrm{e}^{-} \\
\text {Total } & 1 / 2 \mathrm{O}_{2}+\mathrm{H}_{2} \rightarrow \mathrm{H}_{2} \mathrm{O}
\end{array}
$$

This fuel cell does not require water supply for the electrode reaction or humidification of the electrolyte (10). In addition, to improve the immobilization of ionic liquids within the polymeric matrix, we introduced partially sulfonated-fluorinated poly(arylene ether) as a functional polar region of which sulfonic acid group was expected to interact with cation of ionic liquids.

In order to operate a PEMFC, the polymer electrolyte membrane should have high conductivity, mechanical strength, and thermal stability. Some of the FHIL composite membranes had high conductivity values over $30 \mathrm{mS} \mathrm{cm}^{-1}$ when they were mixed with much amount of FHIL, whereas too much FHIL resulted in low mechanical strength which was unsuitable for PEMFC operation. Moreover, when the ratio of s-DFBP-HFDP increased, it also made difficult to form a good thin film. Therefore, the single cell test was performed using composite membranes, which had proper mechanical and thermal strengths, while retaining high ionic conductivity. The single cell test was carried out with gas diffusion electrode with Pt/C catalyst (E-TEK, Pt loading of $0.5 \mathrm{mg} \mathrm{cm}^{-2}$ ). The single cell was fed with dry oxygen and hydrogen at $30 \mathrm{~mL} \mathrm{~min}^{-1}$ at ambient pressure. 


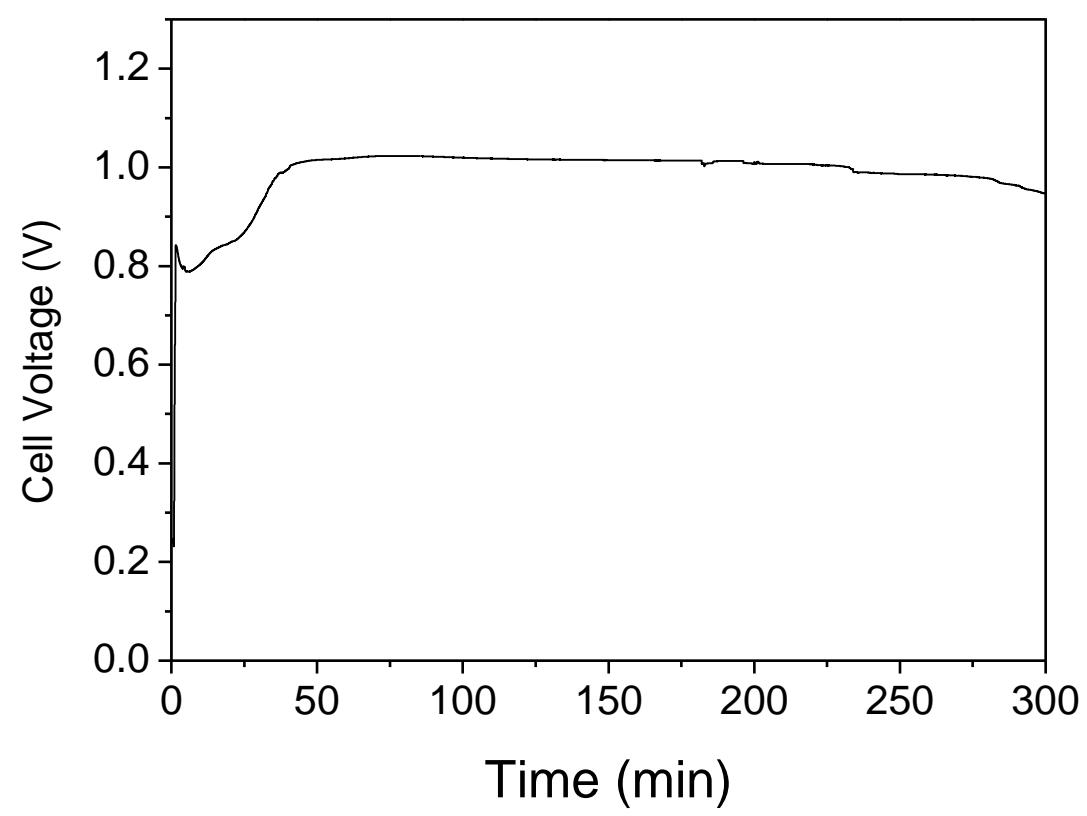

Figure 3. OCV of the single cell using FHIL composite membrane (P(VdF-co-HFP):sDFBP-HFDP:[EMIm] $\left.(\mathrm{FH})_{2.3} \mathrm{~F}=1: 0.3: 1.25\right)$ under dry $\mathrm{H}_{2}$ and $\mathrm{O}_{2}$ flow at $130{ }^{\circ} \mathrm{C}$.

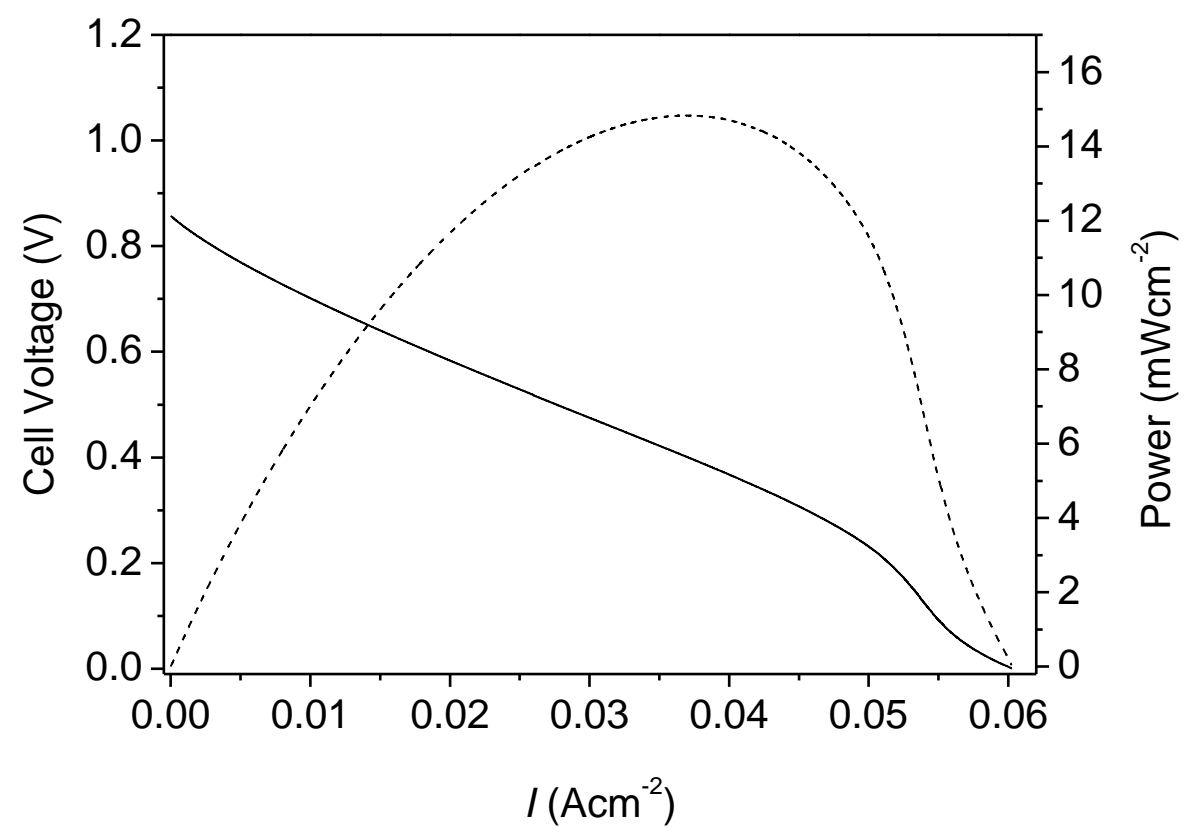

Figure 4. Current-voltage and current-power curves of the single cell using FHIL composite membrane (P(VdF-co-HFP):s-DFBP-HFDP:[EMIm] $\left.(\mathrm{FH})_{2.3} \mathrm{~F}=1: 0.3: 1.75\right)$ under dry $\mathrm{H}_{2}$ and $\mathrm{O}_{2}$ flow at $120{ }^{\circ} \mathrm{C}$. 
Figure 3 shows the open-circuit voltage (OCV) of the fuel cell at $130{ }^{\circ} \mathrm{C}$ using the composite membrane, $\mathrm{P}(\mathrm{VdF}-\mathrm{co}$-HFP $)$ :s-DFBP-HFDP:[EMIm] $(\mathrm{FH})_{2.3} \mathrm{~F}=1: 0.3: 1.25$. The single cell by using of this FHIL composite membrane exhibited OCV at around $1.0 \mathrm{~V}$, which was close to the theoretical value of $1.22 \mathrm{~V}$. The observed difference could be attributed to the gas crossover and the irreversible cathode reaction. Importantly, the PEMFC could be stably operated without humidification at $130{ }^{\circ} \mathrm{C}$ for over $5 \mathrm{~h}$. Figure 4 shows current-voltage and current-power curves of the single cell using FHIL composite membrane, $\mathrm{P}\left(\mathrm{VdF}-\mathrm{co}\right.$-HFP):s-DFBP-HFDP:[EMIm] $(\mathrm{FH})_{2.3} \mathrm{~F}=1.0: 0.3: 1.75$, under dry $\mathrm{H}_{2}$ and $\mathrm{O}_{2}$ flow at $120{ }^{\circ} \mathrm{C}$. The maximum power density reached $14.8 \mathrm{~mW} \mathrm{~cm}^{-2}$ at $37.2 \mathrm{~mA}$ $\mathrm{cm}^{-2}$. Although a potential drop with increasing current density is probably due to the cathodic polarization and to some extent to IR drop, this result shows the possibility of FHIL composite membranes as the polymer electrolyte membrane of unhumidified fuel cells.

\section{Conclusive Remark}

We synthesized novel composite polymer electrolyte membranes of [EMIm] $(\mathrm{FH})_{n} \mathrm{~F}$ ( $n=1.3$ and 2.3) and measured their physical and electrochemical properties. These fluorohydrogenate ionic liquid-based composite membranes have enough thermal stability to operate PEMFCs at temperatures over $100{ }^{\circ} \mathrm{C}$. The ionic conductivities of composite membrane (P(VdF-co-HFP):s-DFBP-HFDP:[EMIm] $\left.(\mathrm{FH})_{2.3} \mathrm{~F}=1: 0.3: 1.75\right)$ were up to 11.3 and $34.7 \mathrm{mS} \mathrm{cm}{ }^{-1}$ at 25 and $130{ }^{\circ} \mathrm{C}$, respectively. We also studied the fuel cell performance using these composite membranes at intermediate temperature without humidification. The OCV was $\sim 1.0 \mathrm{~V}$ under dry hydrogen and oxygen flow at $130{ }^{\circ} \mathrm{C}$ and was stable during the measurement conducted for over $5 \mathrm{~h}$. The maximum power density reached $14.8 \mathrm{~mW} \mathrm{~cm}^{-2}$ at $37.2 \mathrm{~mA} \mathrm{~cm}^{-2}$ at $120{ }^{\circ} \mathrm{C}$. From their good physical and electrochemical properties, the FHIL composite membranes seem to be promising candidate electrolytes for unhumidified PEMFCs at intermediate temperature.

\section{Acknowledgments}

This work was supported by New Energy and Industrial Technology Development Organization (NEDO) of Japan.

\section{References}

1. J. S. Lee, N. D. Quan, J. M. Hwang, S. D. Lee, H. Kim, H. Lee, and H. S. Kim, J. Ind. Eng. Chem., 12, 175 (2006).

2. S. Hommura, Y. Kunisa, I. Terada, M. Yoshitake, J. Fluorine Chem., 120, 151 (2003).

3. C. H. Wirguin, J. Membr. Sci., 120, 1 (1996).

4. C. Yang, P. Costamagna, S. Srinivasan, J. Benziger, A. B. Bocarsly, J. Power Sources, 103, 1 (2001).

5. S. Malhotra and R. Datta, J. Electrochem. Soc., 144, L23 (1997).

6. K. T. Adjemian, S. J. Lee, S. Srinivasan, J. Benziger, A. B. Bocarsly, J. Electrochem. Soc., 149, A256 (2002). 
7. Z. Qi, C. He, A. Kaufman, J. Power Sources, 111, 239 (2002).

8. M. Hickner, H. Ghassemi, Y. S. Kim, B. R. Einsla, J. E. McGrath, Chem. Rev., 104, 4587 (2004).

9. Q. Li, R. He, J. O. Jensen, N. J. Bjerrum, Chem. Mater., 15, 4896 (2003).

10. R. Hagiwara, T. Nohira, K. Matsumoto, and Y. Tamba, Electrochem. Solid-State Lett., 8, A231 (2005).

11. R. Hagiwara, K. Matsumoto, Y. Nakamori, T. Tsuda, Y. Ito, H. Matsumoto, and K. Momota, J. Electrochem. Soc., 150, D195 (2003).

12. H. C. Lee, H. S. Hong, Y.-M. Kim, S. H. Choi, M. Z. Hong, H. S. Lee, and K. Kim, Electrochim. Acta, 49, 2315 (2004). 